\title{
Disease incidence of freshwater fish in the Special Region of Yogyakarta, Indonesia
}

\author{
Yuli Purwandari Kristianingrum ${ }^{1 *}$, Bambang Sutrisno ${ }^{1}$, Sitarina Widyarini ${ }^{1}$, Kurniasih ${ }^{1}$, \\ and Sugiyono ${ }^{l}$ \\ ${ }^{1}$ Department of Pathology, Faculty of Veterinary Medicine, University of Gadjah Mada Jl. Fauna, \\ No.2 Karangmalang, Yogyakarta 55281, Indonesia
}

\begin{abstract}
The potential of freshwater farming in the Special Region of Yogyakarta is very high. Infectious and non-infectious diseases can cause significant economic losses. The main problem of infectious disease is caused by viruses, bacteria, fungi and parasites. This study was conducted to identify diseases that attack freshwater fish using data analysis on fish disease cases in the Laboratory of Pathology, Faculty of Veterinary Medicine, UGM in 2019. A total of 239 cases of fish diseases were examined by the Laboratory Diagnostic Co-assistance students in 2019 from the Special Region of Yogyakarta which includes Sleman district, Kulonprogo district, Yogyakarta City, Bantul district and Gunungkidul district. Based on data analysis, it showed that the highest fish sample was tilapia (52\%), came from Sleman Regency (94\%). The highest disease infection was caused by bacterial infections $(54 \%)$ followed by parasite infections (35\%). Macroscopic changes were observed in the liver (25\%), skin $(19 \%)$. and gills $(26 \%)$. These changes included a yellow swollen liver, ulcer in the skin, fragile consistency and nodules in the surface of kidneys, attachment lamella and necrosis of gill lamellas. The parasite identification resulted in following parasite taxa/species Dactylogyrus., Trichodina sp., Gyrodactylus sp. and Ichtyopthirius sp. in the Parasitology Laboratory. The histopathological changes were identified using the the Hematoxillin \& Eosin staining technique, the organs showed dermatitis (18\%), hepatitis (27\%) and branchitis (23\%). It can be concluded that in this research the highest cases of freshwater fish disease in Yogyakarta Special Region were caused by bacterial infections of tilapia from the Sleman district.
\end{abstract}

\section{Introduction}

Freshwater aquaculture is an alternative to increasing food production, especially in the fisheries sector. One of the most important factors in fish farming management is fish health. Diseases can be caused by environmental physical and chemical factors, feed metabolism, infectious agents, parasites, bacteria, fungi and viruses [1]. The diseases can cause economic losses, growth disorders, and increasing production costs [2].

Special Region of Yogyakarta (DIY) has a great potential development of freshwater aquaculture. Based on data from the Department of Fisheries and Marine Affairs, DIY in 2017 showed that aquaculture production is 11,949 tons, consisting of 300.5 tons (Gunung Kidul 26.2 tons; Bantul 243.8 tons; Kulon Progo 30.5 tons). Cage is 47.1 tons (Gunung Kidul 0.9 tons; Bantul 21.6 tons; Kulon Progo 2.5 tons; Sleman 17.5 tons; and Yogyakarta 4.6 tons). Floating nets 146.9 tons (Gunung Kidul 0.5 tons; and Kulon Progo 146.4 tons).

*Corresponding author : yuli_purwandari@mail.ugm.ac.id 
Brackish water is 300.5 tons ( 2 tons of milkfish; 2.9 tons of tiger prawns; and 295.6 tons of vanamae shrimp) [3]. Disease identification in freshwater fish farming was conducted an effort to treat, prevent and control fish diseases in order to prevent fish mortality and economic losses. This activity involved four laboratories: Pathology, Parasitology, Microbiology and Clinical Pathology. This study aimed to identify diseases that attack freshwater fish in the Special Region of Yogyakarta base on data in the Pathology Laboratory, Faculty of Veterinary Medicine, UGM in 2019. The data analysis can be used to determine the level of disease incidence in freshwater fish farming as a basis for control, prevention and treatment of freshwater fish disease in the Special Region of Yogyakarta.

\section{Materials and methods}

This research was carried out by analyzing fish examination and necropsy data from January to December 2019 at the Pathology Laboratory, Faculty of Veterinary Medicine, University of Gadjah Mada, Yogyakarta (FKH-UGM), Yogyakarta Special Region.The samples came from Sleman, Kulonprogo, Yogyakarta, Bantul and Gunungkidul district. This research was conducted by taking data from fish samples that had been detected by Laboratory Diagnostic Co-assistance students in the Pathology Laboratory, FKH UGM, especially from fish that showed symptoms of illness, including: hemorrhage / bleeding on the skin and fins, ulcers, exopthalmus, weak fish, swimming on the surface. The fish data were supported by data from examination results in the Laboratory of Clinical Pathology, Microbiology and Parasitology, Faculty of Veterinary Medicine, University of Gadjah Mada.

\subsection{Result Analysis}

The data has been obtained and grouped based on the type of fish, fish origin, macroscopic and microscopic changes, disease diagnosis and were analyzed descriptively and semiquantitatively.

\section{Results and Discussion}

Based on the results of data analysis showed 239 samples of fish. The most fish samples were Parrot (126 sampels (52\%)). Data on these types of fish can be seen in table 1 .

Table 1. Fish species that were necropsied of Pathology Laboratory in 2019

\begin{tabular}{cccccccc}
\hline $\begin{array}{c}\text { Types of } \\
\text { fish }\end{array}$ & Parrot & Catfish & Carp & Pomfret & Patin & Goldfish & Other \\
\hline Total & 126 & 29 & 26 & 33 & 14 & 5 & 6 \\
\hline
\end{tabular}

Based on Table 1, it was showed that most samples originated from tilapia fish in the Pathology Laboratory during 2019 compared to other fish species. This was due to that tilapia has the largest population in the Special Region of Yogyakarta compared to other fish species. Data from the Department of Marine Affairs and Fisheries (DKP), DIY showed that tilapia production was 105,000 tons per year. Cultivation of tilapia has many advantages, including that this fish can breed quickly, can be maintained in narrow ponds, has a wide adaptation range and a high tolerance to environmental changes. In addition, tilapia meat does not contain much cholesterol, the price is relatively cheap than other fish and the meat is thick enough to make fillets [4]. Based on the location of origin of fish, The 
most cases of tilapia came from Sleman district. A total of 226 fish (94\%) samples came from Sleman Regency, DIY. These data can be observed in Table 2.

Table 2. The origin of examined fishes in Pathology Laboratory in 2019

\begin{tabular}{cccccc}
\hline Origin & Sleman & Bantul & Kulonprogo & Gunungkidul & Kota Yogya \\
\hline Total & 226 & 10 & 1 & 0 & 2 \\
\hline
\end{tabular}

Table 2 showed that the location of origin of most fish samples came from Sleman Regency, DIY. Because of the highest population fish was in Sleman district compared to other districts in DIY. The area has a abundant water flow for freshwater fish farming. Based on data from the Department of Marine Affairs and Fisheries (DKP) of the DIY Government, it shows that the population of fish farming is 11,410.4 tons, consist of Gunung Kidul district of 305.3 tons; Bantul district of 976.7 tons; Kulon Progo district of 2,255.3 tons; Sleman district of 7,847.7 tons; and Yogyakarta of 25.4 tons. Cultivation of fish in the rice field area is also 156.7 tons, in Sleman district is 156.6 tons; and Yogyakarta 0.1 tons. Meanwhile, 47.1 tons of fish cultivation in the keramba were in Gunung Kidul district of 0.9 tons; Bantul of 21.6 tons; Kulon Progo of 2.5 tons; Sleman of 17.5 tons; and Yogyakarta 4.6 of tons [3]. In addition, it is also influenced by the location of the Pathology Laboratory, FKH-UGM which is in Sleman Regency, so that the close distance will affect the number of samples examined in the laboratory. Samples from other districts such as Bantul, Kulon Progo and Kota Yogyakarta also exist but in very small numbers (6\%). Data Analysis based on infectious agents of fish after examination at the Laboratory of Pathology, Parasitology, Clinical Pathology and Microbiology showed that bacterial infections were the most disease agents compared to other disease agents. These data can be observed in Table 3 .

Table 3. Disease agents examined in Pathology Laboratory in 2019

\begin{tabular}{rccccc}
\hline Agents & Bacteria & Parasite & Fungi & Traumatic & Healthy \\
\hline Total & 157 & 103 & 8 & 7 & 13 \\
\hline
\end{tabular}

The table 3 showed that the disease agents with highest species amount were bacterial infections compared to other disease agents, such as parasites and fungi. As many as $54 \%$ of total disease cases were caused by bacterial infections. This bacterial infection was caused by different bacteria, namely Aeromonas sp., Edwarsiella sp., Pseudomonas sp., Aeromonas sp. infection was the most common infectious agent by bacteria isolation and identification in the Laboratory of Microbiology. Parasitic infection cases were also quite high as much as $35 \%$ of the total cases. Cases of disease infection in a fish were not always caused by one disease agent, but were often caused by more than one disease agent, for example bacteria infection and parasitic infection.

Aeromonas hydrophila is an opportunistic pathogenic bacteria that can causes diseases in fish. Fish suffering from stress or experiencing other diseases predisposed to $A$. hydrophila infection. Bacteria exist in the water environment, so that sub-optimal water and environmental conditions are also a factor in the occurrence of infection [5]. In the case of acute infection, severe septicemia can result in rapid mortality of fish. Macroscopic changes in the fish show exopthalmus, redness of the skin and accumulation of fluid causing abdominal distension. The skin can hemorrhage and ulcers into the dermis. The liver will become pale, and the kidneys will become swollen and brittle. In chronic 
infection, ulcers and skin breakdown will occur due to hemorrhage and inflammation. Both the dermis and epidermis are ulcer and part of the necrotic muscle [6].

A. hydrophila bacteria produce endotoxin and exotoxin which play a role in causing the disease. Endotoxins are an integral part of the cell wall structure of Gram negative bacteria. Endotoxin biological activity is associated with the presence of lipopolysaccharide (LPS) which is the main component of the outer membrane surface of the A. hydrophila bacterial cell [7]. In addition, A. hydrophila bacteria produce enterotoxins (aerolysin), cytotoxins (Act), and two cytotonic toxins (Ast and Alt). Aerolysin is thought to be an enterotoxin that can produce hemolytic and cytotoxic effects. Act is a cytotoxin that can increase tumor levels of 9 necrotic factor- $\alpha$ (TNF- $\alpha$ ) and interleukin-1 $\beta$ (IL-1 $\beta$ ), which can cause inflammation and tissue necrosis in the presence of A. hydrophila infection. A. hydrophila also produces lipase enzymes in the form of glycerophospholipid: cholesterol acyltransferase (GCAT), protease enzymes in the form of metallo-proteases and serineproteases, and nuclease enzymes. This enzyme is thought to function to maintain bacteria in a variety of environments, including the host. These enzymes are used to damage tissue and degrade substrates used in bacterial metabolism [8].

Confirmation of the diagnosis of Aeromoniasis was carried out by isolating and identifying bacteria through biochemical testing including motility tests, IMViC (Indole, Methyl Red, Voges Proskauer and Citrat), urease, gelatinase, oxidation-fermentation, DNAse, and sugar testing including glucose, sucrose, lactose., mannitol, and maltose in the Laboratory of Microbiology, Faculty of Veterinary Medicine UGM.

Based on the analysis of macroscopic examination on fthe examined ish, it showed that there were several pathogenic changes in fish organs, such as in skin, liver, gills, kidneys, spleen, heart and digestive tract. The results of data analysis of macroscopic changes in the fish can be observed in table 4 .

Table 4. Macroscopic examination in the fish organ of Pathology Laboratory in 2019

\begin{tabular}{ccccccccc}
\hline Organs & Skin & $\begin{array}{c}\text { Live } \\
\mathrm{r}\end{array}$ & Gills & $\begin{array}{c}\text { Kidney } \\
\mathrm{s}\end{array}$ & Muscle & Spleen & Hearth & $\begin{array}{c}\text { Digestiv } \\
\mathrm{e}\end{array}$ \\
\hline Total & 107 & 142 & 148 & 55 & 42 & 17 & 3 & 36 \\
\hline
\end{tabular}

Based on the table above, it showed that the highest macroscopic changes in disease cases in fish were observed in the gills by $26 \%$, followed by the liver as much as $25 \%$, skin by $19 \%$, kidneys as much as $8 \%$, muscle fins by $7 \%$, digestion by $6 \%$ and other organs. as much as $3 \%$. Macroscopic changes in the gills were in the form of pale gills, necrosis of lamellae and mucus. Meanwhile, macroscopic changes in the skin included hemorrhage (bleeding) in the skin, fins, eyes, skin ulcers (furunculosis), exopthalmus and cloudiness in the eyes. Macroscopic changes in the internal organs of fish can be observed in Figure 1. 


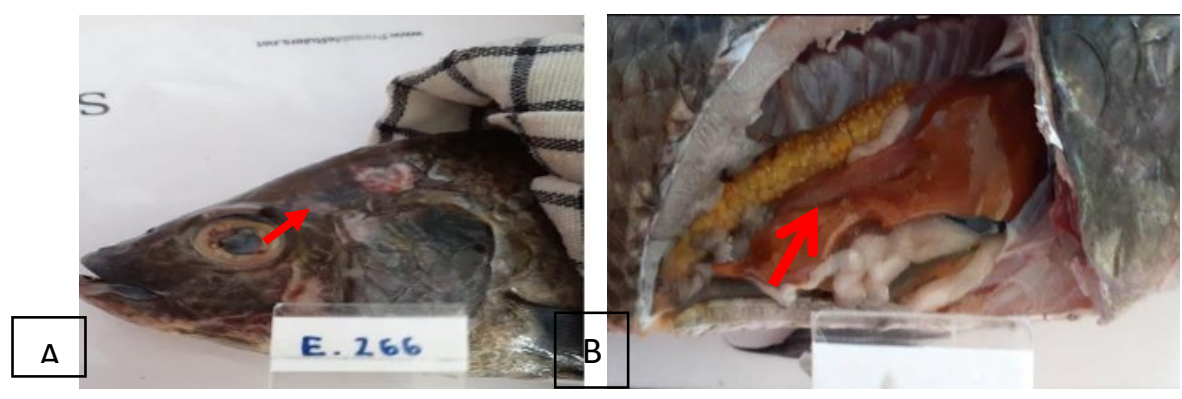

Fig. 1. A. Tilapia with reddish skin lesion, ulcer, hemorhage and cloudy eye (arrow), B. The liver was swelling, yellowis, fragile (arrow) [9].

The figure above showed that a macroscopic change of tilapia with hemorrhage in the eyes, ulcers on the skin. Pathological changes in the eye area and skin can be caused by several factors. One of them was caused by a bacterial infection, namely the Aeromonas sp. A. hydrophila infections were characterized by the presence of red spots on the skin surface (hemorrhage), necrosis of the fins, ulcers on the skin and necrosis of the muscles. However, erosion or necrosis of the skin can also be caused by several things, including trauma, parasitic infections, and other bacterial infections [10]. Based on the observation of the macroscopic changes, the liver appeared swollen yellow, the consistency was fragile, the incision area was wet/oily, and the tip of the lobe was blunt. Macroscopic observations of the kidneys showed swelling, a fragile consistency and nodules on the surface of the kidney. While the heart organs appeared red and swollen. The gills also appeared to have lamella adhesion, pale color, gill lamella necrosis and parasites were found on native examination in the Laboratory of Parasitology, FKH-UGM. The parasitic agents include: Dactylogyrus sp., Trichodina sp., Gyrodactylus sp., Ichtyopthirius sp. According to [10], the condition of stressed fish will show clinical symptoms, including: the color of the fish's skin becomes darker with reddish hemorrhage spots on the entire body surface and the base of the fins and ascites.

Based on the analysis of microscopic examination with Hematoxillin \& Eosin (H\&E) staining, it showed that there were several changes in the fish organs, such as: skin, liver, gills, kidney, spleen, heart and digestive tract. The results of data analysis of microscopic changes in the fish can be observed in table 5.

Table 5. Microscopic examination in the fish organ of Pathology Laboratory in 2019

\begin{tabular}{ccccccccc}
\hline Organs & $\begin{array}{c}\text { Branch } \\
\text { itis }\end{array}$ & $\begin{array}{c}\text { Hepat } \\
\text { itis }\end{array}$ & $\begin{array}{c}\text { Derma } \\
\text { titis }\end{array}$ & $\begin{array}{c}\text { Uvei } \\
\text { tis }\end{array}$ & $\begin{array}{c}\text { Nephr } \\
\text { itis }\end{array}$ & $\begin{array}{c}\text { Splen } \\
\text { itis }\end{array}$ & $\begin{array}{c}\text { Gastri } \\
\text { tis }\end{array}$ & $\begin{array}{c}\text { Pericard } \\
\text { itis }\end{array}$ \\
\hline Total & 172 & 205 & 141 & 65 & 67 & 19 & 54 & 20 \\
\hline
\end{tabular}

Table 5 showed that the most microscopic changes were observed in the liver, gills and skin. In the liver of $27 \%$ (hepatitis), gills of $23 \%$ (branchitis), skin of $18 \%$ (dermatitis), eyes of $8 \%$ (uveitis), kidneys of $9 \%$ (nephritis), digestive tract of $7 \%$ (gastritis and enteritis), other organs of $4 \%$ (splenitis and pericarditis). Microscopic changes in fish organs can be observed in Figure 2. 

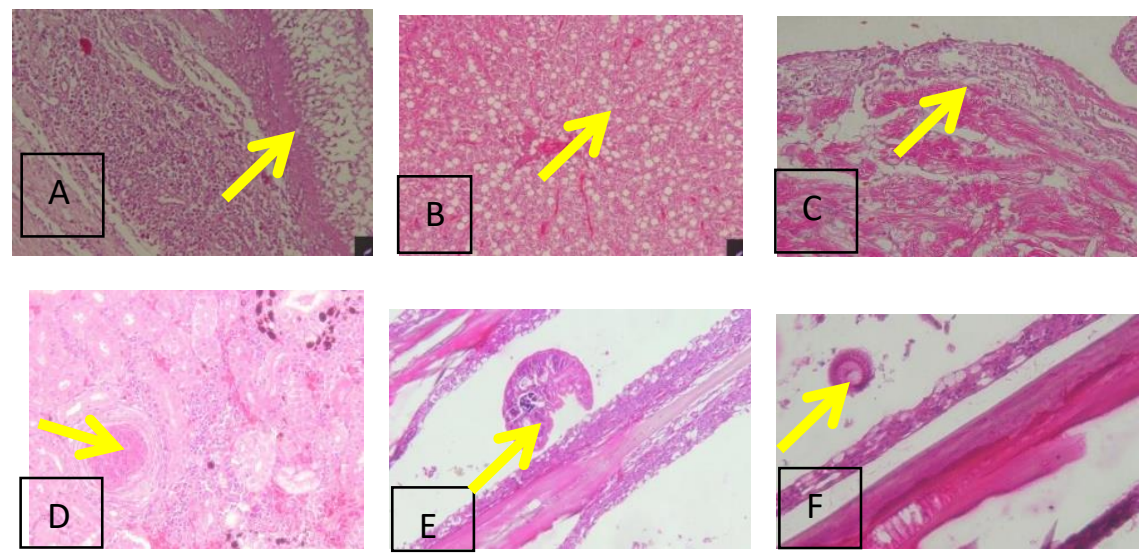

Fig. 2. A. The skin was hemorrhage, heterophyl, limfocyt, fibroblast infiltration, B. Fat vacuole in the hepatocyt and congestion, C. Heterophyl and limfocyte infiltration in the pericard, D. Granulomatous inflamation in the kidney ginjal, E. Dactylogyrus sp. in the between of primer lamella of gill, F. Trichodina sp. in the between of primary lamella of gill, with necrosis of secondary lamella and limfocyte infiltration (HE, 40x) [11] [21].

Macroscopic changes in the liver appeared a yellow, fragile consistency, the incision area was wet/oily, and the tip of the lobe was blunt, while the microscopic examination showed hepatocyt swelling with a clearly vacuole in the cytoplasm, so that the liver was fatyy degeneration. Some livers also developed to hepatitis with inflammatory cell infiltration, accompanied by accumulation of water or fat in the cytoplasm (Figure 2B). Fatty degeneration in the liver can be caused by low nutritional quality, vitamin deficiencies, and bacteria extracellular toxins [12]. A. hydrophila infection has been reported by [13], it can cause degenerative changes in the form of well-defined vacuolization of liver cells.

Microscopic changes of branchitis in the gills showed that proliferation of secondary lamellae epithelium so that fusion lamellae, accompanied by lymphocyte cell infiltration and found of parasites, both worm and protozoa in the secondary and primary lamellae (Figure 2E and F). The worms that were seen among the secondary lamellae were Dactylogyrus sp., Gyrodactylus sp., While the protozoa included Trichodina sp., Ictyoptirius sp., Heneguya sp. Seen from the measurement results the length of the worms were about $500 \mu \mathrm{m}$. According to data from [14] and [15], Dactylogyrus sp. can reach 2 $\mathrm{mm}$, has a long, flat shape with a hook in the form of a hamulus (opisthaptor) and a marginal hook, a blood suction device, and there are two pairs of eye spots on the anterior end. [16] also states that these parasites are found mainly in gills. The worm is elongated flat, has two pairs of eye spots on the anterior end as well as a hook and suction device at the end. On the posterior side there are two separate transverse bars. According to [17] and [16], Dactylogyrus sp., monogeneous oviparous trematodes are flattened, have 2 pairs of eyes anteriorly, 14 marginal hooks, toothed head and 1-2 pairs of anchors posteriorly.

Microscopic changes showed dermatitis in the skin, the heart has pericarditis and granulomatous inflammation of the kidneys. Dermatitis lesions on the skin were characterized by edema in the dermis and hemorrhages and heterophyl cell infiltration in the reticular stratum which then leads to spongiosis. Pathological changes in the skin are indicated by the presence of ulceration of the epidermis followed by necrosis of hemorrhage that extends into the underlying muscle tissue [12]. On microscopic examination of the kidneys, there was an increase in the melanomacrofag center between the renal tubules, and a granulomatous inflammation was seen, which was characterized by 
a necrosis center surrounded by inflammatory cells and connective tissue (2D). Aeromonas hydrophila bacterial infection is characterized by the proliferation of hemosiderin which forms the melanomacrofag center (MMC) in visceral organs such as the liver, kidneys and spleen. Melanomacrofag center (MMC) has four pigments, namely melanin, lipofusine, seroid, and hemosiderin. Hemosiderin accumulation (hemosiderosis) is formed due to an increase in erythrocyte destruction in organs which results of decrease in the number of mature erythrocytes in the circulation [18, 16,12]. Granulomatous inflammation is formed as an effort to defend the host against persistent irritants, both exogenous and endogenous. Aeromonas hydrophila is one of the irritants that is difficult to phagocyte, this is due to its virulence factors, including capsules, $\mathrm{O}$ antigen on lipopolysaccharides, S-layer and glucon [19].

Bacterial infection can also be caused by Edwardsiella tarda. This bacterial infection in tilapia showed clinical symptoms including excessive mucus production, abnormal swimming behavior (spiral or floating), exopthalamus and cloudy eye, skin discoloration, muscle hemorrhage and smelling gas, enlarged spleen and kidneys, liver changes. color, abscesses in the internal organs and there is an accumulation of mucoid fluid in the body cavity. Fish skin ulcerates up to the muscles, hemorrhage on the fins, reddish lesions on the head and around the mouth, inflammation of the peritoneum and intestines [20]. The skin has hemorrhage petechiae and necrosis of the muscles, sometimes the skin ulcers and loses scales.

\section{Conclusion}

Based on the analysis of freshwater fish examination data in the Pathology Laboratory in 2019 , it was showed that the highest cases of disease occurred in tilapia caused by bacterial infections with macroscopic and microscopic changes in the skin, eyes and internal organs and the most fish cases were from the Sleman district, Special Region of Yogyakarta.

Thanks for Faculty of Veterinary Medicine for funding this research through the Development Fund in 2020, Faculty of Veterinary Medicine, UGM.

\section{References}

1. H. Handajani and S. Samsundari, Parasit dan Penyakit Ikan. (UMM Press, Malang, 2005)

2. K.M.G. Kordi, Penanggulangan Hama dan Penyakit Ikan. (Bina Adiaksara dan Rineka Cipta, Jakarta, 2004)

3. .Anonim, http://mfec.kkp.go.id/index.php/arsip/c/3/Profil-Kelautan-dan-PerikananProvinsi-D.I.-Yogyakarta/ (19 Maret 2020).2017

4. H. Khairuman and K. Amri, Budi Daya Ikan Nila, (Agromedia, Jakarta, 2013)

5. Kordi, K.M.G. Penanggulangan Hama dan Penyakit Ikan. (Bina Adiaksara dan Rineka Cipta, Jakarta, 2013)

6. B. Markey, F. Leonard, M. Archambault, A. Cullinane, D. Maguire, Clinical Veterinary Microbiology 2nd Edition (Mosby Elsevier, Edinburg, 2013)

7. R. C. Cipriano, and B. Austin, Furunculosis and Other Aeromonas Disease, (CAB Internasional, Oxfordshire, 2011)

8. Triyaningsih, Sarjito, B. P. Slamet, Patogenesitas Aeromonass hydrophila yang diisolasi dari Lele Dumbo (Clarias gariepinus) yang berasal dari Boyolali, Journal of Aquaculture Management and Technology 3, 11- 17 (2014) 
9. D.J. Brenner, N.R. Krieg, J.T. Staley, G.M. Garrity, Bergey's Manual of Systematic Bacteriology. Volume 2, Part B. (William \& Wilkins, USA, 2005)

10. H.P. Rosmala, Infeksi Aeromonas hydrophila serta infestasi Dactylogyrus sp. pada Ikan nila dengan Nomor Protokol E. 266. Laporan Koasistensi Diagnosa Laboratorik. Fakultas Kedokteran Hewan, UGM (2019)

11. B. Austin, and D.A. Austin, Bacterial Fish Pathogens Diseases of Farmed and Wild Fish. Fifth Edition. (Springer Praxis Publishing, German, 2012)

12. H.P. Aditya, Infeksi Aeromonas hydrophila serta infestasi Dactylogyrus sp. pada Ikan Bawal (Colossoma macropomum) dengan Nomor Protokol E. 148 Laporan Koasistensi Diagnosa Laboratorik. Fakultas Kedokteran Hewan, UGM (2019)

13. R.J. Robert, Fish Pathology.Fourth Edition. (Blackwell Publishing, UK, 2012)

14. R. Harikrishnan, C. Balasundaram, Y. Moon, M. Kim, J. Kim, M. Heo, Use of herbal concoction in the therapy of goldfish (Carassius auratus) infected with Aeromonas hydrophila, Bull. Vet. Inst. Pulawy 53, 27-36 (2009)

15. W. Nurcahyo, Parasit pada Ikan (Gadjah Mada University Press, Yogyakarta, 2014)

16. L. S. Roberts and J. Janovy, Foundation of Parasitology, 8th Edition (McGraw-Hill, New York, 2009)

17. E J. Noga, Fish Disease: Diagnosis and Treatment Second Edition (Wiley-Blackwell, Singapore, 2010)

18. P. T. K. Woo, Fish Disease and Disorders Vol I: Protozoan and Metazoan Infection (CABI, Oxfordshire, 2006)

19. N.H. Hamid, M.D. Hassan, M.D. Sabri, A.H. Hasliza, R.H. Hamdan, M.N.F. Afifah, M.S. Raina, A.B.S. Nadia, M.M. Fuad, Studies on Pathogenicity Effect of Aeromonas hydrophila Infection in Juvenile Red Hybrid Tilapia Oreochromis sp. in Proceeding of International Seminar on Livestock Production and Veterinary Technology: 532-539. DOI: http://dx.doi.org/10.14334/Proc.Intsem.LPVT-2016-p.532-539 (2016)

20. J.M. Tomas, The Main Aeromonas Pathogenic Factors. Int. Schol. Research Net, 1-22 (2012)

21. J. F. Leatherland and P. T. K. Woo, Fish Diseases and Disorders, Volume 1 Protozoan and Metazoan Infection \& Volume 3 Viral, Bacterial and Fungal Infections, 2nd Edition (VetBooks.ir). (CAB International, London, 2010)

22. A.D. Risang, Infeksi Aeromonas hydrophila dan infestasi Dactylogyrus sp. serta Trichodina heterodentata pada Ikan Lele (Clarias batrachus) dengan Nomor Protokol E.267 Laporan Koasistensi Diagnosa Laboratorik. Fakultas Kedokteran Hewan, UGM. (2019) 